\title{
A STUDY ON CAPABILITIES OF DIFFERENT ELECTRODE MATERIALS DURING ELECTRICAL DISCHARGE MACHINING (EDM)
}

\author{
Muataz Hazza Faizi Al Hazza*, Ahsan Ali Khan, Mohammad Yeakub \\ Ali, Siti Fatihah Hasim and Mohd Radzi Che DaUd \\ Department of Manufacturing and Materials Engineering, \\ Faculty of Engineering, International Islamic University Malaysia, \\ Jalan Gombak, 53100 Kuala Lumpur, Malaysia. \\ *Corresponding author: muataz@iium.edu.my \\ (Received: $18^{\text {th }}$ Oct. 2016; Accepted: $5^{\text {th }}$ Feb. 2017; Published on-line: $1^{\text {st }}$ Dec. 2017)
}

\begin{abstract}
Electrode material in the electro discharge machining (EDM) process plays an important role in terms of material removal rate (MRR), electrode wear rate (EWR) and surface roughness (Ra). The purpose of this research is to investigate the capability of different electrode materials: copper, aluminum, and graphite in EDM of AISI 304 stainless steel as a work piece. The research focuses on three current settings: $2.5 \mathrm{~A}, 4.5 \mathrm{~A}$, and $6.5 \mathrm{~A}$ using kerosene as a dielectric fluid. The experiment was planned and analyzed using the full factorial of experimental design using response surface methodology (RSM). In this research, two outputs have been investigated: MRR and EWR. The results indicated that the responses increased with the increase in current. Finally, the desirability function method has been used to determine the optimum values. The results show that maximum MRR and minimum EWR were achieved using a graphite electrode at current $6.5 \mathrm{~A}$.
\end{abstract}

ABSTRAK: Bahan elektrod dalam proses pengeluaran elektron pada mesin EDM berperanan penting dalam kadar pengeluaran bahan (MRR), kadar penggunaan ekektrod (EWR) dan kekasaran permukaan (Ra). Kajian ini bertujuan bagi menilai keupayaan pelbagai jenis bahan elektrod yang berlainan: tembaga, aluminium, dan grafit dalam EDM pada AISI 304 keluli tahan karat sebagai bahan kajian. Fokus kajian ini pada tiga takat arus: $2.5 \mathrm{~A}, 4.5 \mathrm{~A}$ dan $6.5 \mathrm{~A}$ menggunakan kerosin sebagai cecair dielektrik. Eksperimen ini telah dirancang dan diuji menggunakan faktorial penuh pada binaan eksperimen menggunakan kaedah tindak balas pada permukaan (RSM). Dalam kajian ini, dua keputusan telah diuji: MRR dan EWR. Keputusan menunjukkan tindak balas bertambah dengan kenaikan arus. Akhirnya kaedah fungsi keperluan telah digunakan untuk mencari nilai optimum. Keputusan menunjukkan MRR maksimum dan EWR minimum telah dicapai menggunakan elektrod grafit pada arus $6.5 \mathrm{~A}$.

KEYWORDS: EDM; electrode material; material removal rate; electrode wear rate; surface roughness

\section{INTRODUCTION}

Electro-discharge machining (EDM) is a thermoelectric process during which the heat energy of the spark produced between the electrodes is used to erode materials from the electrodes [1]. The performance of the EDM process is measured by different outputs such as: material removal rate (MRR), electrode wear rate (EWR) and surface roughness (Ra). Many factors that control those outputs such as: peak current, polarity, pulse duration, 
power supply voltage, and many others. However, selection of the electrode materials is one of the more important aspects that require care in EDM. This is because the improper selection of the electrode materials may cause poor machining characteristics. An improper electrode material may cause less MRR, leading to more machining time, leading to high EWR. Many researchers have discussed and investigated the effect of current and electrode material and their effect on the MRR and EWR. However, machining characteristics change greatly when using different electrode materials due to the different erosion removal resistance [2].

Lee and Li compared three different electrode materials: graphite, copper-tungsten, and copper and their effect on MRR, EWR and surface roughness with different peak currents ranging from $12 \mathrm{~A}$ to $64 \mathrm{~A}$ [3]. They found that peak current was almost directly proportional to the MRR of these three electrodes; as peak current increased, the MRR also increased. Among these three electrodes, graphite obtained better machining performance since it provided the highest MRR. Graphite was followed by copper-tungsten, and lastly, copper. The study showed that low peak current provided a low electrode wear ratio for the graphite electrode but that the opposite was true for the copper electrode. At the highest peak current, the copper electrode showed the highest EWR, while the copper-tungsten electrode always gave the lowest electrode wear ratio at all ranges of peak current. Other than that, analysis also showed a relationship between surface roughness and peak current. As peak current increased, surface roughness also increased for all electrode materials.

Singh et al. [4] studied four different electrode materials: copper, copper-tungsten, brass, and aluminum in the machining En-31 tool steel. The results showed that the copper and copper-tungsten had low wear rates. Copper and aluminum showed high surface roughness when high current values were used.

Jahan et al. [5] investigated the fine-finish die-sinking micro-EDM of tungsten carbide using different electrode materials namely, tungsten (W), copper tungsten $(\mathrm{CuW})$, and silver tungsten $(\mathrm{AgW})$ electrodes. The results obtained showed that during the EDM process, surface roughness becomes dependent mostly on the discharge voltage. The researchers further stated that during fine-finish micro-EDM, the pulse energy supplied into the gap needs to be minimized. Furthermore, electrical and thermal properties of the electrode material were founded to greatly affect the surface finish. It was found that the $\mathrm{AgW}$ electrode provided a smooth surface with the lowest $\mathrm{Ra}$ value among the three electrodes. For the MRR characteristic, the $\mathrm{CuW}$ electrode provided the highest value, followed by $\mathrm{AgW}$, especially at high gap voltage. In case of EWR, the W electrode was best, followed by $\mathrm{CuW}$ and $\mathrm{AgW}$, as it gave the lowest wear during EDM. After reviewing all the performance parameters, the best electrode material for finish die-sinking microEDM of tungsten carbide was selected to be $\mathrm{AgW}$.

However, this research focused on using different tool electrode materials during the EDM of AISI 304 stainless steel. This will include investigation of the effect of various electrode materials and peak currents on material removal rate (MRR) and electrode wear rate $(\mathrm{EWR})$.

\section{EXPERIMENTAL PROCEDURE}

Three different electrode materials have been tested: copper $(\mathrm{Cu})$, aluminum $(\mathrm{Al})$ and graphite (C) with three levels of current: 2.5 A, 4.5 A and 6.5 A. The dielectric fluid used was kerosene. The material removal rate (MRR) and electrode wear rate (EWR) have been 
investigated. In this experiment, full factorial design has been used to conduct the experiment. Nine (9) runs were conducted. Table 1 concluded the maximum and minium boundaries of the experiment. The physical properties of the three different electrodes are concluded in Table 2. Table 3 concluded the setting of the machine during experiment.

Table 1: Experimental design

\begin{tabular}{ccc}
\hline Run & Electrode Material & Current (A) \\
\hline 1 & Copper & 2.5 \\
2 & Aluminum & 6.5 \\
3 & Aluminum & 2.5 \\
4 & Copper & 4.5 \\
5 & Graphite & 6.5 \\
6 & Graphite & 2.5 \\
7 & Graphite & 4.5 \\
8 & Aluminum & 4.5 \\
9 & Copper & 6.5 \\
\hline
\end{tabular}

Table 2: Physical properties of electrode materials

\begin{tabular}{lccc} 
& \multicolumn{3}{c}{ Electrode Material } \\
\cline { 2 - 4 } Physical properties & Aluminum & Copper & Graphite \\
\hline Electrical resistivity $(\Omega . \mathrm{m})$ & $2.65 \times 10^{-8}$ & $1.68 \times 10^{-8}$ & $3-60 \times 10^{-5}$ \\
Electrical conductivity $(1 / \Omega . \mathrm{m})$ & $3.77 \times 10^{7}$ & $5.95 \times 10^{7}$ & $0.33-0.167 \times 10^{4}$ \\
Thermal conductivity & $227 \mathrm{~W} / \mathrm{m} . \mathrm{K}$ & $380.7 \mathrm{~W} / \mathrm{m} . \mathrm{K}$ & $160 \mathrm{~W} / \mathrm{m} . \mathrm{K}$ \\
Melting point & $660{ }^{\circ} \mathrm{C}$ & $1083{ }^{\circ} \mathrm{C}$ & $3550{ }^{\circ} \mathrm{C}$ \\
Specific heat & $0.9 \mathrm{~J} / \mathrm{g}^{\circ} \mathrm{C}$ & $0.092 \mathrm{cal} / \mathrm{g}^{\circ} \mathrm{C}$ & $0.17-0.2 \mathrm{cal} / \mathrm{g}^{\circ} \mathrm{C}$ \\
Specific gravity at $20{ }^{\circ} \mathrm{C}$ & $2.73 \mathrm{~g} / \mathrm{cm}^{3}$ & $8.9 \mathrm{~g} / \mathrm{cm}^{3}$ & $1.75 \mathrm{~g} / \mathrm{cm}^{3}$ \\
Coefficient of thermal expansion & $24 \times 10^{-6}{ }^{\circ} \mathrm{C}^{-1}$ & $6.6 \times 10^{-6}{ }^{\circ} \mathrm{C}^{-1}$ & $7.8 \times 10^{-6}{ }^{\circ} \mathrm{C}^{-1}$ \\
\hline
\end{tabular}

Table 3: Experimental settings

\begin{tabular}{cc}
\hline Experimental conditions & Value \\
\hline Gap voltage & $20 \mathrm{~V}$ \\
Pulse ON time & $10.0 \mu \mathrm{s}$ \\
Pulse OFF time & $6.0 \mu \mathrm{s}$ \\
Spark gap & $0.010 \mathrm{~mm}$ \\
Depth of cut & $1.0 \mathrm{~mm}$ \\
Dielectric fluid & Kerosene \\
Electrode polarity & Negative \\
Work piece polarity & Positive \\
\hline
\end{tabular}

\section{RESULTS}

The results of conducting nine experiments are concluded in Table 4. MRR and EWR have been calculated using the following formulas:

$$
\begin{aligned}
& \operatorname{MRR}(g / \mathrm{min})=(W P w b(g)-W P w a(g)) / T m \\
& \operatorname{EWR}(g / \mathrm{min})=(E w b(g)-E w a(g)) / T m
\end{aligned}
$$


Where $W P w b(g)$ is the weight of the work piece before machining, $W P w a(g)$ weight of work piece after machining, $E w b(g)$ is the weight of electrode before machining, $E w a(g)$ is the weight of electrode after machining and $\mathrm{Tm}$ is the machining time.

Table 4: Results of full factorial experiment

\begin{tabular}{ccccc}
\hline Run & Electrode Material & Current (A) & MRR (g/min) & EWR (g/min) \\
\hline 1 & Copper & 2.5 & 0.0099 & 0.0006 \\
2 & Aluminum & 6.5 & 0.5109 & 0.0032 \\
3 & Aluminum & 2.5 & 0.0129 & 0.0009 \\
4 & Copper & 4.5 & 0.1259 & 0.0013 \\
5 & Graphite & 6.5 & 0.5957 & 0.0011 \\
6 & Graphite & 2.5 & 0.0565 & 0.0003 \\
7 & Graphite & 4.5 & 0.2608 & 0.0006 \\
8 & Aluminum & 4.5 & 0.1522 & 0.0023 \\
9 & Copper & 6.5 & 0.433 & 0.0025 \\
\hline
\end{tabular}

The relationships between MRR and EWR with the current for each type of material have been plotted in Fig. 1. The best EWR was achieved with a graphite electrode. However, the current negatively affects the EWR, whereas the effect of electrode material on MRR was unclear. Finally, the MRR increased with the increase of current.

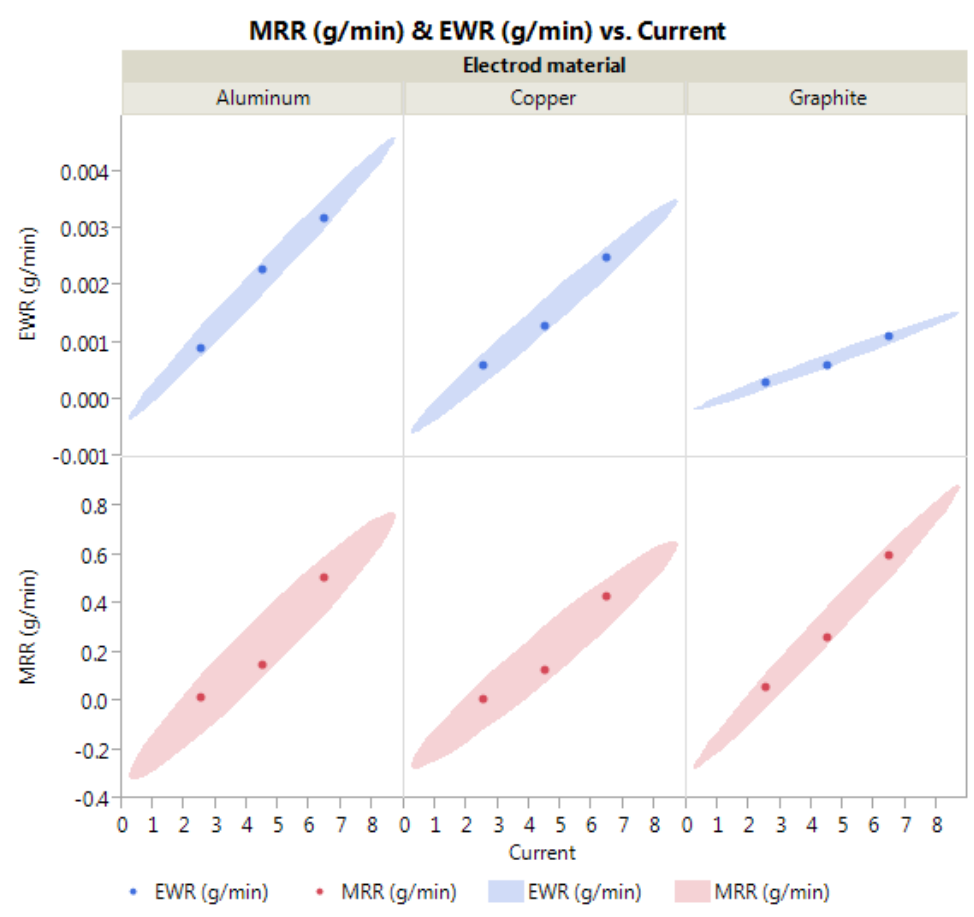

Fig. 1: relationships between MRR and EWR with the current and material.

\subsection{D Profile}

The 3D profile for MRR and TWE have been created using JMP software to lend a greater understanding of the effect of peak current and different electrode materials, as shown in Fig. 2. 


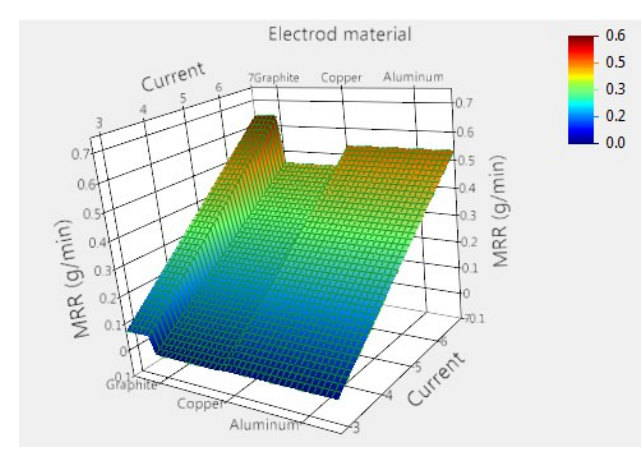

a) MRR

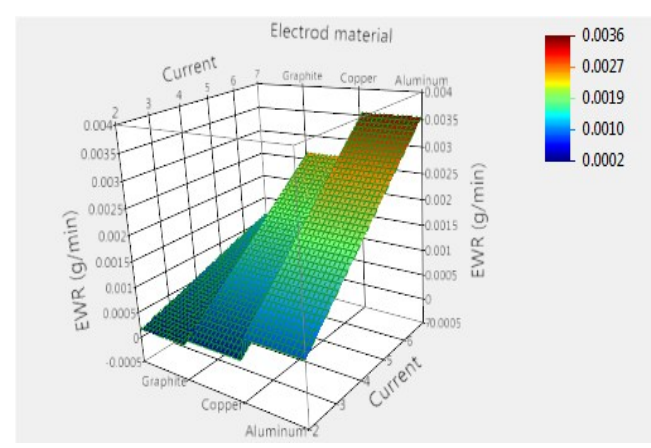

b) EWR

Fig. 2: 3D surface profile.

The results showed that higher MRR can be achived using a graphite electrode, followed by the performance of the aluminium electrode, with the copper electrode showing the lowest performance for the different current values. On the other hand, the least EWR was recorded for the graphite electrode, followed by the copper electrode and ending with the aluminium electrode for all current values.

\subsection{Statistical Analysis}

The results were analyzed statistically using different presentation tools: regression plot, summary of fit, and comparison was made between actual and predicted values. Figure 3 supported the results shown in the $3 \mathrm{D}$ profile, where the best material for both the higher removal rate and lower wear rate for the electrode was graphite. Finally, the measured data and the predicted results have been plotted for both MRR and EWR, as shown in Fig. 4.

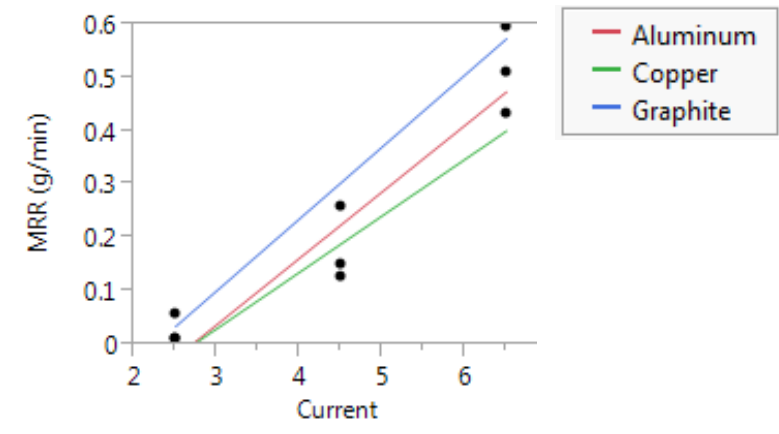

a) MMR

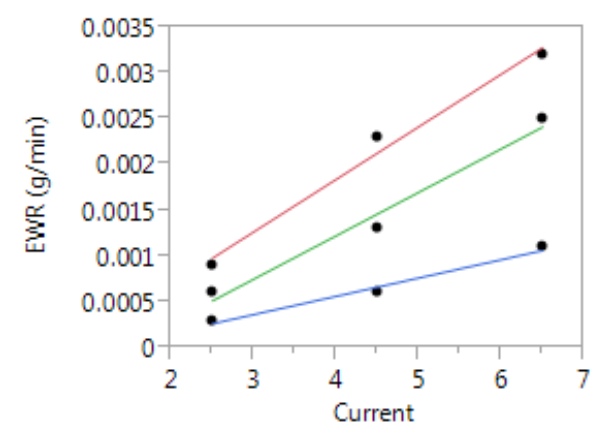

b) EWR

Fig. 3: Regression plot.

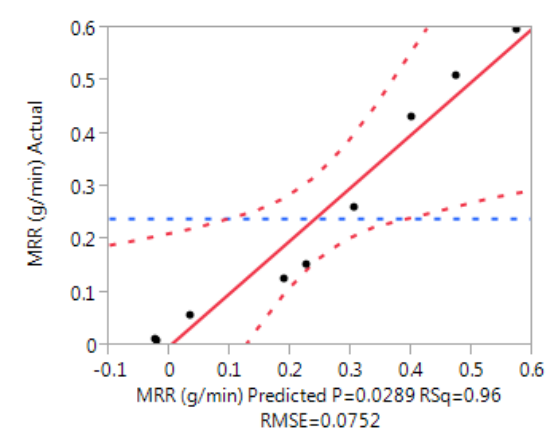

a) MRR

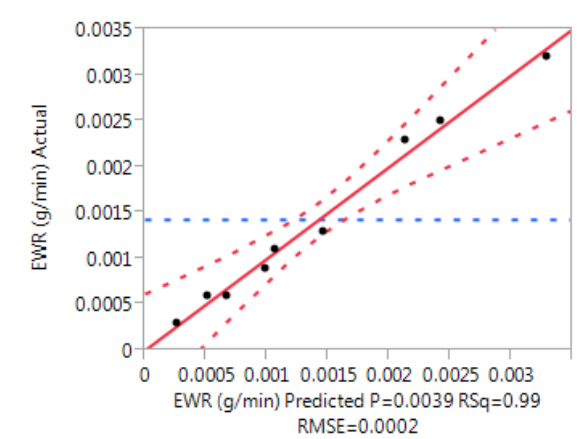

b) EWR

Fig. 4: Actual and predicted plots. 
The results showed high correlation, justified by calculating the summary fit measures that have been concluded in Table 5 .

Table 5: Summary of fit

\begin{tabular}{lcc}
\hline & MRR & EWR \\
\hline R-Square & 0.957 & 0.989 \\
R-Square Adj & 0.886 & 0.970 \\
\hline
\end{tabular}

Table 5 shows that $\mathrm{R}^{2}$ was close to one in all models and was very close to unity with the adjusted $\mathrm{R}^{2}$, meaning that the models were reliable for predicting the different parameters.

\section{DESIRABILITY FUNCTION}

The desirability function method has been implemented to achieve the maximum MRR and the minimum EWR. The results are presented in Fig. 5. The figure shows that with $76 \%$ and using graphite material for electrode, the MRR will be $0.5739 \mathrm{~g} / \mathrm{min}$. The optimization results have been included in Table 6. The best ratio of MRR to EWR can be achieved using a graphite electrode with 6.5 as a current with the ratio of 537.9 with higher desirability of $76 \%$.

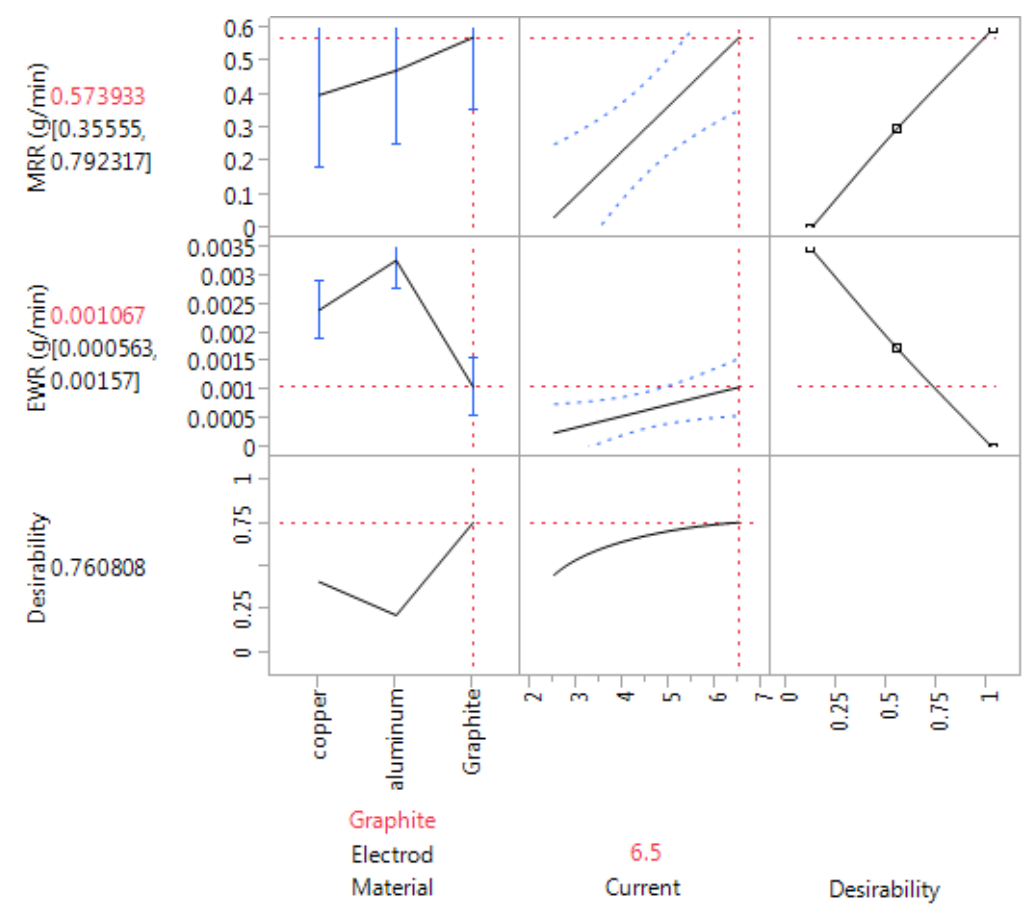

Fig. 5: Optimization using a desirability function.

Table 6: Optimization results

\begin{tabular}{lccccc}
\cline { 2 - 6 } & $\begin{array}{c}\text { Current } \\
\text { (A) }\end{array}$ & $\begin{array}{c}\text { MRR } \\
(\mathbf{g} / \text { min) }\end{array}$ & $\begin{array}{c}\text { EWR } \\
(\mathbf{g} / \mathbf{m i n})\end{array}$ & $\begin{array}{c}\text { Ratio } \\
\text { (MRR/EWR) }\end{array}$ & $\begin{array}{c}\text { Desirability } \\
\text { \% }\end{array}$ \\
\hline Graphite & 6.5 & 0.573933 & 0.001067 & 537.8941 & $76 \%$ \\
Copper & 6.5 & 0.40115 & 0.002417 & 165.9702 & $41 \%$ \\
Aluminum & 6.5 & 0.474333 & 0.003283 & 144.4816 & $22 \%$ \\
\hline
\end{tabular}




\section{CONCLUDING REMARKS}

The results of this study have been analysed and can be concluded by the following:

i. For all different types of electrode material, increasing the current will increase both the MRR and EWR. In other words, increasing the current has a positive effect on MRR and a negative effect on EWR. Therefore, the best measure was to take the ratio of MRR to EWR.

ii. The desirability function, as one of the surface response methods, has been applied to determine the best cutting conditions. The results showed that by using the highest current of $6.5 \mathrm{~A}$ and the graphite electrode can give the best ratio of MRR to EWR of 534 with the desirability of $76 \%$.

iii. The MRR increased when the current increased. For this analysis, the graphite electrode gave the higher MRR $(0.5957 \mathrm{~g} / \mathrm{min})$ compared to aluminum and copper electrodes.

\section{ACKNOWLEDGEMENT}

We would like to show our gratitude to the Research Management Center (RMC), International Islamic University Malaysia (IIUM) for their support to conduct our research. We would like also to thank our colleagues in the Department of Manufacturing and Materials Engineering.

\section{REFERENCES}

[1] Kumar S, Dave H K, Desai KP. (2016). Experimental investigation on performance of different tool movement strategies in EDM process for boring operation. The International Journal of Advanced Manufacturing Technology, 87(5-8):1609-1620.

[2] Reynaerts D, Hendrik VB. (1997) Microstructuring of silicon by electro-discharge machining (EDM) — part I: Theory. Sensors and Actuators A: Physical, 60(1):212-218.

[3] Lee SH, Li XP. (2001) Study of the effect of machining parameters on the machining characteristics in electrical discharge machining of tungsten carbide. J. Materials Proc. Tech., 115(3):344-358.

[4] Singh S, Maheshwari S, Pandey PC. (2004). Some Investigations Into The Electric Discharge Machining of Hardened Tool Steel Using Different Electrode Materials. J. Materials Proc. Tech., 149(1):272-277.

[5] Jahan MP, Wong YS, Rahman M. (2009) A study on the fine-finish die-sinking micro-EDM of tungsten carbide using different electrode materials. J. Materials Proc. Tech., 209(8):3956-3967. 